\title{
Фізична терапія дітей молодшого шкільного віку з типовою вродженою клишоногістю
}

\author{
Ціж Л. М., Романчишин I. \\ Львівський державний університет фізичної культури, м. Львів, Україна
}

Актуальність. Вроджена клишоногість займає одне 3 перших місць за поширеністю серед вроджених аномалій опорно-рухового апарату. Важливо оцінити функціональні можливості ураженої стопи, опорну функцію для правильного підбору лікувальних та реабілітаційних заходів.

Мета дослідження: проаналізувати вплив фізичної терапії на показники функціонального стану опорно-рухового апарату дітей молодшого шкільного віку з вродженою клишоногістю.

Матеріали та методи. У дослідженні брали участь 12 дітей, які проходили курс фізичної терапії за удосконаленою методикою, що включала ЛФК, масаж, фізіотерапію та ортопедичні засоби. ЛФК проводилась у формі лікувальної гімнастики, самостійних занять та лікувальної ходьби.

Використовували гоніометрію, мануальне м'язове тестування, плантографію, оцінку інтенсивності болю за ВАШ, антропометрію, шкалу оцінки якості життя дітей Пірса Харріса, середнє арифметичне значення, середнє квадратичне відхилення, вірогідність різниці за критерієм Стьюдента, зіставлення одновимірних показників у процентах.
Результати дослідження та їх обговорення. Аналіз плантограм за методом I. М. Чижина показав значну різницю у довжині та ширині стопи, зміни у висоті підйому стопи та відхилення кута п'ятки.

За час дослідження амплітуда згинання стопи збільшилася з 71 до 83\% від меж норми, амплітуда розгинання стопи збільшилася з 52 до $63 \%$ від меж норми. Найбільші обмеження спостерігалися в еверсії стопи, яка за час дослідження збільшилася на $8 \%$.

Збільшилася сила розгиначів стопи. Спостерігали покращення рівноваги та збільшення часу утримання певного положення стоячи. Якість життя у сферах «щастя» та «задоволеність» склала 13,5 бали при нормі 15.

Висновки. Удосконалена методика сприяла змінам функціонального стану ОРА.

Перспективи подальших досліджень: вивчення питання якості життя дітей 3 даною патологією.

Ключові слова: клишоногість, дитина, фізична терапія. 